\title{
Konvergensi Media Surat Kabar Harian Lokal Jateng Pos
}

\author{
Ahsani Taqwim Aminuddin dan Nurul Hasfi \\ Universitas Diponegoro, Semarang, Indonesia \\ Email: ahsanitaqwem@gmail.com
}

\begin{abstract}
The development of information and communication technology has resulted in the following of mass media towards technological developments related to a shift in media consumption patterns to digital media. This study aims to determine the efforts of media convergence undertaken by Jateng Pos in Semarang, Central Java. This qualitative descriptive study uses a single instrumental case study approach, where researchers identify and analyze a specific issue. Data are obtained from interviews with sources, books, articles, and other related literature. By using the concept of media convergence from Siapera and Veglis, this research show that Jateng Pos adopts four types of media convergence which are related to each other: a) technological convergence by managing online media (jatengpos.co.id) and being present on social media such as Instagram, Twitter and Facebook; b) convergence of content that combines forms of writing, photos and videos; c) business convergence, where unlimited connectivity on the Internet adds business partners (advertisers) not only from Central Java, but throughout Indonesia; d) professional convergence by preparing human resources capable of producing and distributing various types of needed content based on the platform.
\end{abstract}

Keywords: Jateng Pos, local daily newspaper, media convergence, media management

\begin{abstract}
Abstrak
Perkembangan teknologi informasi dan komunikasi menyebabkan media massa mulai mengikuti perkembangan teknologi terkait adanya pergeseran pola konsumsi media ke media digital. Penelitian ini bertujuan untuk mengetahui upaya konvergensi media pada surat kabar harian lokal Jateng Pos di Semarang, Jawa Tengah. Penelitian deskriptif kualitatif ini menggunakan pendekatan studi kasus instrumental tunggal, dimana peneliti mengidentifikasi dan menganalisis satu isu spesifik. Data diperoleh dari hasil wawancara dengan narasumber, buku, artikel, serta literatur terkait lainnya. Dengan menggunakan konsep konvergensi media dari Siapera dan Veglis, penelitian ini menunjukkan bahwa Jateng Pos mengadopsi empat tipe konvergensi media yang berkaitan satu sama lain: a) konvergensi teknologi dengan mengelola media online (jatengpos.co.id) dan hadir di media sosial seperti Instagram, Twitter dan Facebook; b) konvergensi konten yang mengombinasikan bentuk tulisan, foto dan video; c) konvergensi bisnis, dimana keterhubungan tanpa batas di Internet menambah mitra bisnis (pengiklan) bukan hanya dari Jawa Tengah, tapi seluruh Indonesia; serta d) konvergensi profesional dengan cara mempersiapkan SDM yang mampu memproduksi dan mendistribusikan berbagai macam konten yang dibutuhkan berdasarkan platformnya.
\end{abstract}

Kata-kata Kunci: Jateng Pos, konvergensi media, koran harian lokal, pengelolaan media

\section{PENDAHULUAN}

Era digital mempengaruhi berbagai aspek kehidupan manusia termasuk media massa tradisional. Hal krusial yang sering menjadi pertanyaan yakni akankah keberadaan media tradisional tergeser oleh media digital - dalam hal ini internet? Pada tahun 2012, Center for the Digital Future di USC Annenberg School for Communication and Journalism meramalkan bahwa dalam lima tahun hanya surat kabar besar yang bisa bertahan. Belakangan, Rupert

Korespondensi: Ahsani Taqwim Aminuddin, Jurusan Magister Ilmu Komunikasi, Fakultas Ilmu Sosial dan Ilmu Politik Universitas Diponegoro. Jl. Erlangga Barat VII, No. 33, Semarang. Email: ahsanitaqwem@gmail.com

Menyerahkan: Desember 2019, Diterima: Desember 2019, Terbit: Januari 2020

ISSN: 2549-0559 (cetak), ISSN: 2549-1946 (online), Website: http://jurnal.unpad.ac.id/kajian-jurnalisme 
Murdoch meramalkan bahwa mungkin tidak ada lagi surat kabar dalam satu dekade kedepan (Price, 2015). Di Inggris, seiring perkembangan teknologi dan persaingan di industri media yang ketat, sejumlah media menutup kantor berita lokal. Antara bulan Juni 2008 dan Maret 2009, 25 kantor telah ditutup dan 60 rubrik serta sekitar 1000 pekerja editorial kehilangan pekerjaan. Hal ini terjadi karena surat kabar memotong biaya dan pekerjaan di ruang berita, saat pendapatan mereka turun. Saat media lokal tutup, disisi lain media online menjadi penyedia informasi yang diminati, seperti blog hingga video di YouTube. Di Amerika, Tribune Company, penerbit Los Angeles Times dan Chicago Tribune, mengalami kebangkrutan pada Desember 2008. Pada saat yang sama, New York Times Company mencari pinjaman jutaan dolar dari markas besarnya (Lundén, 2009).

Pergeseran pola konsumsi media di Malaysia berbeda dengan media di Amerika. Pola konsumsi media dari media konvensional ke media baru bukan diakibatkan karena kemudahan akses dan tutupnya beberapa media karena pendapatan yang menurun. Penggunaan media baru dalam mencari berita dan informasi diakibatkan karena media konvensional yang dikendalikan oleh negara. Tidak seperti halnya di negara lain, pengaruh buruk munculnya media baru terhadap media lama masih bisa dikelola di Malaysia. Warga Malaysia masih lebih memilih untuk mengakses berita melalui surat kabar, radio dan televisi, sehingga surat kabar Bahasa Malaysia masih mengalami peningkatan sirkulasi. Namun, beberapa peneliti berpendapat bahwa orang Malaysia memilih mengakses media online karena kebijakan negara yang mengatur media mainstream. Pemerintah Malaysia menentukan siapa yang boleh atau tidak boleh membangun dan menjalankan perusahaan media cetak dan penyiaran. Dengan kata lain, parameter kebebasan dan ruang di media mainstream secara langsung atau tidak langsung ditentukan oleh pemerintah. Oleh karena itu, tidak mengherankan jika banyak orang Malaysia beralih ke media alternatif untuk menemukan informasi, berita, dan pandangan baru (Salman, Ibrahim, Abdullah, Mustaffa, \& Mahbob, 2011)

Sama halnya dengan perusahaan media di Amerika, dalam konteks Indonesia, fenomena media mainstream, terutama media cetak yang gulung tikar sudah terindikasi dalam lima tahun terakhir. Sinar Harapan resmi tidak terbit lagi pada awal tahun 2016 lalu yang merupakan media besar di dekade tahun 1980-an. Di tahun 2015, kebijakan Sinar Harapan untuk berhenti cetak disusul juga oleh beberapa media cetak skala nasional. The Jakarta Globe, pengelola surat kabar harian berbahasa Inggris ini, tidak lagi cetak pada September 2015 dan sepenuhnya beralih menjadi media online. Setelah itu, Tempo juga menghentikan penerbitan edisi koran minggu pada Oktober 2015, dan berubah menjadi 'Tempo Akhir Pekan' bergabung dengan edisi Sabtu. Harian Bola dan Soccer yang sama-sama dari Grup Kompas Gramedia juga telah beralih menjadi media online pada Oktober 2014. Hal yang sama juga dialami juga oleh Harian Jurnal Nasional, Majalah Trax yang merupakan majalah musik dan gaya hidup, Indonesia Finance Today, Tabloid Bola, Majalah Fortune, Majalah Otomotif, serta Majalah Bloomberg (Karman, 2017). Berikut beberapa media cetak yang telah berhenti produksi dalam bentuk cetak di Indonesia seperti terlihat pada tabel 1.

Fenomena ini menunjukkan adanya peralihan pola konsumsi dari media cetak ke media baru. Hasil penelitian memberikan peringatan kepada media khususnya media cetak, surat kabar (Rusadi, 2014). Saat ini, generasi yang mengkonsumsi media adalah generasi muda yang disebut sebagai digital native yang telah meninggalkan media cetak seperti surat kabar, sehingga jika media tidak menyediakan layanan platform yang sesuai dengan kebiasaan dan kebutuhan mereka, maka perusahaan media cetak akan ditinggalkan. Penelitian ini pula menegaskan bahwa sebaiknya media tidak hanya terpaku pada produk berita offline saja, industri media berita harus sudah menggunakan multiplatform berbasis offline dan online. Khalayak saat ini dengan 
perkembangan teknologi telah memiliki banyak pilihan dan kemudahan untuk mengkonsumsi berita dan informasi berbasis internet seperti portal berita, media digital, media sosial yang berbeda dengan generasi digital settler dan immigrant (Rusadi, 2014).

Tabel 1. Beberapa Media Cetak di Indonesia yang Telah Berhenti Cetak

\begin{tabular}{|l|l|l|l|}
\hline \multicolumn{1}{|c|}{ Media Cetak } & \multicolumn{1}{|c|}{ Terbit } & \multicolumn{1}{c|}{$\begin{array}{c}\text { Berhenti } \\
\text { sejak }\end{array}$} & \multicolumn{1}{c|}{ Pemilik/Grup media } \\
\hline $\begin{array}{l}\text { Koran Sinar } \\
\text { Harapan }\end{array}$ & $\begin{array}{l}\text { Terbit oertama tahun 1961, } \\
\text { kemudian di breidel tahun 1986 dan } \\
\text { terbit kembali pata tahun 2001 }\end{array}$ & 2016 & PT Sinar Harapan Persada \\
\hline Jakarta Globe & 12 November 2008 & 2016 & $\begin{array}{l}\text { Lippo's Group BeritaSatu } \\
\text { Media Holdings (BSMH) }\end{array}$ \\
\hline Tabloid Bola & $\begin{array}{l}\text { Awalnya terbit pada 3 Maret 1984. } \\
\text { sebagai sisipan harian KOMPAS }\end{array}$ & Oktober 2018 & $\begin{array}{l}\text { Tahun 1984 terbit sebagai } \\
\text { sisipan harian KOMPAS. 4 } \\
\text { tahun kemudian kemudian } \\
\text { diterbitkan terpisah }\end{array}$ \\
\hline Soccer & Tahun 2000 & Oktober 2014 & KOMPAS Gramedia \\
\hline Majalah Trax & Tahun 2002 & Februari 2016 & PT Media Tiara Victory \\
\hline $\begin{array}{l}\text { Rolling Stones } \\
\text { Indonesia }\end{array}$ & Tahun 2005 & 1 Januari 2018 & $\begin{array}{l}\text { Rolling Stones dan PT A\&E } \\
\text { Media }\end{array}$ \\
\hline $\begin{array}{l}\text { Gaul } \\
\text { Tabloid ini terbit pertama kali tahun } \\
\text { 2002 }\end{array}$ & Tahun 2014 & PT Nuansa Karya Berita \\
\hline $\begin{array}{l}\text { Majalah HAI } \\
\text { Semar Harian Joglo }\end{array}$ & Tahun 2007 & Juni 2017 & PT Penerbitan Sarana Bobo \\
\hline $\begin{array}{l}\text { Harian BERNAS } \\
\text { (koran lokal) }\end{array}$ & 15 November 21946 & Awal tahun & PT Joglosemar Prima Media \\
\hline $\begin{array}{l}\text { Semarang Post } \\
\text { (koran lokal) }\end{array}$ & Tahun 2002 & 1 Maret 2018 & PT Media Bernas Jogja \\
\hline
\end{tabular}

Sumber: Diolah dari berbagai sumber, tahun 2005 sampai 2018.

Kebangkrutan media cetak yang diindikasikan dengan beralihnya mereka ke format online tidak lepas dari adanya perkembangan teknologi komunikasi dan informasi yang mengubah pola konsumsi pembaca (reader). Perkembangan teknologi baik perangkat keras maupun perangkat lunak mempermudah khalayak dalam mengakses informasi melalui media online (internet). Tidak hanya dinikmati dalam lingkup keluarga, dengan hadirnya smartphone, informasi langsung datang ke setiap individu yang terhubung dengan internet atau media sosial. Adanya teknologi tablet dan smartphone memungkinkan adanya digitalisasi madia konvensional (Fidler, 2003). Bentuk-bentuk komunikasi interpersonal dengan menggunakan perantara perangkat keras seperti komputer akan membaurkan suara, video, teks dan grafik seperti yang telah dilakukan di Twitter, Facebook, YouTube dan lainnya (Vebrynda, Maryani, \& Abdullah, 2017).

Fakta lain dari keterpurukan media adalah bahwa industri surat kabar sudah mulai ditinggalkan. Hal ini karena generasi muda lebih percaya pada blog dan media online, sehingga surat kabar perlu mengembangkan distribusi berita mereka ke media online. Tidak mengherankan apabila sudah semakin banyak media cetak nasional yang memiliki versi online, karena akan menjadi ruang untuk partisipasi warga negara melalui pemberian komentar. Media cetak tidaklah mati, tetapi media cetak membutuhkan bantuan untuk tetap hidup, sehingga industri media membutuhkan strategi konvergensi media dari media cetak ke digital (Nugroho, Siregar, Laksmi, \& Media, 2012). 
Data yang dirilis Asosiasi Penyelenggara Jasa Internet Indonesia pada tahun 2017 tentang penetrasi pengguna internet di Indonesia, ditemukan bahwa sebanyak 143,26 juta masyarakat Indonesia menggunakan internet dari total penduduk sebanyak 262 juta jiwa. Dengan sebaran yang didominasi di pulau Jawa yakni $58,08 \%$. Hal ini karena teknologi internet dan fasilitas yang telah mendukung di pulau Jawa. Adanya fakta tentang meningkatnya pengguna internet khususnya di pulau Jawa serta meningkatnya jumlah media online memperlihatkan bahwa di era digital ini, migrasi ke teknologi digital tidak dapat dihindarkan. Namun demikian, terpusatnya internet di kota besar terutama Jakarta tidak mengharuskan media mainstream di tingkat lokal untuk segera melakukan migrasi. Hal ini disebabkan karena selain pengguna internet masih rendah di tingkat lokal, mereka juga masih memiliki pembaca setia yang masih suka membaca media versi cetak. Hal ini menyebabkan media cetak lokal berada di posisi abuabu, dimana disatu sisi mereka harus tetap mempertahankan tradisi lama, dan disisi lain mereka harus mampu beradaptasi menyambut era digital (APJII, 2017)Sweden.

Dalam kajian media baru, terdapat perbedaan mendasar antara media konvensional dan media baru yang disebut sebagai First Media Age (Broadcast) dan Second Media Age (Interactivity) (Holmes, 2005). Perbedaan historis antara media konvensional dan media baru yakni, First Media Age (media massa) bersifat terpusat, memiliki komunikasi satu arah, cenderung berada dibawah pengaruh dan kontrol negara, menjadi instrumen bagi rezim stratifikasi dan ketidaksetaraan, peserta terfragmentasi dan dipandang sebagai suatu massa, serta memengaruhi kesadaran khalayak, sedangkan Second Media Age (media baru) bersifat tersebar (many to many), memiliki komunikasi dua arah, menghindari kontrol negara, lebih demokratis (memfasilitasi kewarganegaraan universal), pesertanya dipandang tetap bisa mempertahankan individualitas mereka, sehingga pengaruhnya langsung kepada pengalaman individu dalam ruang dan waktu tertentu.

Penelitian terdahulu terkait konvergensi media lokal yang mengkaji strategi manajemen Suara Merdeka untuk mempertahankan eksistensi dalam menghadapi media kompetitor di Jawa Tengah serta strategi manajemen media dalam mengantisipasi perkembangan media online. Hasilnya menyatakan bahwa Suara Merdeka meningkatkan kembali tiras dan market share untuk mempertahankan eksistensi perusahaan. Suara Merdeka juga melakukan konvergensi media lokal dengan membentuk jaringan pemberitaan Suara Merdeka Network yang menjaring media cetak harian, media online, TV lokal dan radio. Melalui jaringan tersebut akan tercapai efisiensi karena semua wartawan tergabung dalam satu jaringan berita dan dimanfaatkan untuk memasok lebih banyak media (Ayunita, 2013).

Di tingkat nasional, grup media nasional juga ikut mulai melakukan upaya konvergensi, salah satunya adalah Media Group yang menaungi dua media yakni media cetak Media Indonesia dan televisi Metro TV. Penelitian lainnya menunjukkan bahwa pihak Media Group memberlakukan kebijakan integrasi antara kedua media tersebut yakni Media Indonesia dan Metro TV, serta melakukan konvergensi unik, yakni melakukan integrasi acara antara Media Indonesia yang cetak dan Metro TV yang elektronik, bukan hanya pada acara namun juga pertukaran dan perputaran karyawan. Selain untuk keuntungan ekonomi, hal ini juga untuk mendidik karyawan yakni jurnalis kedua media ini agar mampu dapat menguasai serta memiliki keterampilan ganda seperti menulis di media cetak dan menulis narasi televisi (Samatan, 2009).

Tren baru industri komunikasi juga menghadirkan inovasi-inovasi pengelolaan media cetak lokal di berbagai daerah, seperti pemanfaatan internet media lokal Tribun Jogja, yang menunjukkan bahwa strategi 3M (Multimedia, Multichannel dan Multiplatform) sebagai strategi dalam proses konvergensi dan kemudian bertransformasi menuju full convergence (Khadziq, 2016). Dengan hal ini, media yang berada di bawah jaringan Tribun akan mendapatkan 
keuntungan melalui pasokan pengiklan, begitu pula spesialisasi yang memungkinkan penyaluran konten berita secara real-time dapat mengurangi biaya tenaga kerja, administratif, dan material. Begitu juga yang dilakukan oleh Solo Pos yang mempersiapkan platform digital mereka untuk menghadapi media digital yang terus tumbuh. Model konvergensi media yang dilakukan Solo Pos adalah model konvergensi news gathering di mana dalam model ini seorang jurnalis dituntut untuk mampu mencapai tingkatan multitasking (Prihartono, 2016)one of them is Solopos. This research is a qualitative descriptive study. Descriptive study by Whitney (in Nazir, 1988: 63.

Jateng Pos yang menjadi objek penelitian ini merupakan jaringan grup Jawa Pos yang berada di Semarang, Jawa Tengah. Pada hasil tahap pra-penelitian ini, ditemukan fakta bahwa Jateng Pos merupakan resurgence dari grup Jawa Pos di Semarang, Jawa Tengah, yang bangkit kembali dengan harapan akan memberikan warna baru dan semangat baru media cetak lokal di era digital ini. Grup Jawa Pos yang berada di Semarang, Jawa Tengah, pada awalnya terdiri dari Radar Semarang, Meteor, dan Semarang Post yang telah mewarnai media lokal di Semarang selama sekitar 2,5 tahun. Namun pada tahun 2005, harian Grup Jawa Pos, yakni Semarang Post dan Meteor, pada akhirnya gulung tikar karena mengalami kerugian. Diakui bahwa media ini pernah memiliki tiras hingga 15 ribu eksemplar. Namun, perlahan-lahan jumlah pembacanya terus menurun. Jateng Pos sebagai bentuk baru dari media Grup Jawa Pos yang telah lama mati di Semarang, mencoba untuk dibangkitkan kembali dengan warna dan strategi yang dinilai berbeda (wawancara dengan Alkomari, Redaktur cetak Jateng Pos, 2017). Hal inilah yang menjadi latar belakang penelitian ini, yang menjadikan media lokal Jateng Pos sebagai situs penelitian tentang konvergensi media lokal di era digital.

Untuk mencapai visi yang diharapkan, pihak manajemen Jateng Pos membutuhkan sebuah strategi baru yang sesuai dengan era saat ini. Kaitannya dengan penelitian tentang konvergensi media, strategi diartikan sebagai rencana jangka panjang yang disatukan, luas, dan berintegrasi yang menghubungkan keunggulan strategis perusahaan media cetak lokal dengan tantangan lingkungan, yang dirancang untuk memastikan bahwa tujuan utama dari perusahaan dapat dicapai melalui pelaksanaan yang tepat oleh organisasi (Wheelen \& Hunger, 2015).

Konvergensi media menjadi hal yang sangat penting dan dibutuhkan oleh media cetak lokal maupun nasional untuk dapat bertahan dan menjaga eksistensi di era keterhubungan dengan bantuan internet saat ini. Munculnya internet, media sosial, dan teknologi digital di abad ke-21 mempercepat evolusi dalam jurnalisme dan komunikasi. Evolusi itu mengubah hubungan antara produsen berita dan konsumen. Mengubah batas-batas geografis dalam mendefinisikan komunitas, dan berpengaruh pula pada model organisasi dan ekonomi media. Konvergensi mulai mencakup berbagai dimensi dari kolaborasi lintas media ke penggunaan berbagai media dalam mengumpulkan dan menyampaikan informasi, sehingga dibutuhkan kajian mengenai jurnalisme dan komunikasi massa serta penerapan inovasi yang berkelanjutan (Kolodzy, Grant, DeMars, \& Wilkinson, 2014).

Juan Luis Cebrián, CEO Prisa (media terkemuka di Spanyol) merasa tidak yakin bahwa dalam lima belas tahun media cetak akan terus berjalan seperti kita mengenalnya saat ini. Media cetak akan tetap ada jika kita memperjuangkannya dan melakukan hal yang benar. Hal tersebut diumumkan setelah pemecatan karyawannya dengan alasan re-organisasi internal. Untuk menghadapi tantangan era seperti sekarang dibutuhkan strategi agar dapat mempertahankan eksistensi media. Beberapa peneliti mempelajari sejumlah besar strategi yang diadopsi oleh bisnis media untuk menyesuaikan diri dengan salah satu konsep utama dalam jurnalisme saat ini, yaitu konvergensi (Siapera \& Veglis, 2012). Konvergensi dalam jurnalisme adalah proses 
multidimensional, yang difasilitasi oleh penerapan teknologi komunikasi digital yang meluas, yang juga mempengaruhi aspek teknologi, bisnis, dan editorial media. Hal tersebut mendorong integrasi alat, ruang, metode kerja, dan bahasa, sehingga wartawan bisa menulis konten untuk didistribusikan melalui berbagai platform, dengan menggunakan bahasa yang sesuai di masingmasing media.

Setiap media membangun berbagai strategi konvergensinya masing-masing. Sebagai contoh, Kompas grup mengembangkan beberapa media seperti Kompas.com, kompas TV, serta Kompas.id. Setiap medium dibuat tidak untuk saling mengalahkan medium lainnya. Kompas.id bukan dibuat untuk menggantikan koran Kompas dengan beralih total ke digital, melainkan ingin membuat pilihan untuk para pembacanya — apakah ingin berlangganan koran, digital, atau keduanya (Dhiya \& Fadilah, 2018). Dengan demikian, pilihan medium pada kasus konvergensi di Kompas Grup merupakan strategi untuk mencapai lebih banyak raihan khalayak dengan cara memberikan lebih banyak pilihan medium.

Terdapat empat bentuk konvergensi media yang saat ini diadaptasi oleh berbagai media di dunia, yang dalam penelitian ini dipakai untuk mengidentifikasi konvergensi yang berlangsung di Jateng Pos. Konvergensi yang dimaksud diantaranya: (1) Konvergensi teknologi (multiplatform), yakni pemanfaatan berbagai macam platform atau perangkat digital untuk mereproduksi hampir semua jenis materi sehingga menuntut pekerja media untuk membuat dan menerbitkan materi dalam format yang berbeda; (2) Konvergensi bisnis, artinya bisnis yang sebelumnya dimiliki hanya satu surat kabar berubah menjadi operasi multiplatform. Konvergensi di tingkat bisnis mengarah pada bentuk baru organisasi logistik yang dirancang untuk meningkatkan produktivitas. Media mengatur ulang tim editorial mereka untuk menghasilkan sarana produksi berita yang fleksibel dan beragam yang dapat merespon persyaratan platform digital baru; (3) Konvergensi profesional, yakni wartawan dituntut beradaptasi dengan habitat teknologi yang berkembang, yang membutuhkan keterampilan profesional baru dan sarana organisasi yang juga diperbaharui; (4) Konvergensi isi (multimedia), artinya bahwa teks yang dihasilkan oleh wartawan harus sesuai dengan platform yang digunakan, sebab isi sebuah jaringan menggabungkan kode komunikasi yang berbeda (Siapera \& Veglis, 2012).

Melihat fakta yang telah terjadi dewasa ini, teknologi semakin berkembang pesat tanpa berpatok pada jarak geografis, media cetak perlu melakukan pengembangan ide dan tindakan demi pengembangan media berbasis internet yang akan menembus batas antara jarak, ruang atau fisik, sebab hal tersebut menjadi pertimbangan khalayak dewasa ini dalam mengakses informasi. Mengacu pada fakta bahwa secara praktis perhatian terhadap berita dan informasi yang diproduksi oleh kantor berita konvensional perlu dilakukan kajian yang melihat strategi yang dilakukan media untuk terhindar dari kebangkrutan yang semakin tampak nyata, serta untuk menjaga eksistensi media di era digital seperti saat ini.

Berbeda dengan penelitian sebelumnya yang lebih berfokus pada bagaimana manajemen induk perusahaan mengantisipasi maraknya media online, penelitian ini bertujuan untuk melihat upaya konvergensi media yang dilakukan oleh menajemen surat kabar harian lokal Jateng Pos di Semarang, Jawa Tengah, untuk menjaga eksistensinya di era digital saat ini. Penelitian ini membahas pemanfaatan teknologi oleh media lokal dalam proses produksi berita, distribusi berita dan penggunaan teknologi untuk kerjasama atau bisnis.

\section{METODE}

Penelitian ini merupakan penelitian deskriptif kualitatif dimana peneliti secara sistematis, faktual, dan akurat mendeskripsikan fakta atau objek yang diteliti (Kriyantono, 2014), sehingga penelitian ini hanya memaparkan situasi atau peristiwa yang diteliti dengan observasi yang 
bersifat naturalistic setting, bukan menjelaskan hubungan, serta tidak menguji hipotesis penelitian (Rakhmat, 2009). Penelitian ini menggunakan metode studi kasus, dimana peneliti mengidentifikasi dan menganalisis isu yang spesifik pada suatu organisasi atau individu yang dibatasi waktu dan aktivitas. Peneliti mengumpulkan informasi secara lengkap dengan menggunakan berbagai prosedur pengumpulan data berdasarkan waktu yang telah ditentukan. Desain studi kasus yang digunakan dalam penelitian ini adalah studi kasus tunggal holistik, dimana penelitian ini fokus pada satu isu yang akan dikaji (Yin, 2018), yaitu upaya konvergensi media oleh Jateng Pos untuk mempertahankan eksistensi media cetak lokal tersebut di era digital.

Penelitian ini dilakukan di Semarang selama 2 bulan, tepatnya pada bulan Maret sampai Mei 2017. Data penelitian ini diperoleh dengan melakukan wawancara informal dan tidak terstruktur dengan narasumber, dimana narasumber dipilih menggunakan teknik purposive, serta narasumber dipilih berdasarkan kriteria-kriteria tertentu berdasarkan tujuan riset (Kriyantono, 2014). Narasumber dalam penelitian ini adalah Alkomari yang menjabat sebagai Redaktur Cetak Jateng Pos, Rendra yang menjabat sebagai Redaktur online Jateng Pos, serta Pandji sebagai jurnalis lapangan di Jateng Pos. Data primer dalam penelitian ini bersumber dari informasi yang diberikan oleh para narasumber melalui wawancara mendalam dan observasi. Sedangkan data sekunder diperoleh dari buku, artikel serta literatur-literatur yang berkaitan dengan masalah penelitian.

Setelah data diperoleh dengan wawancara dan observasi, selanjutnya dilakukan reduksi data, penyajian data, lalu penarikan kesimpulan. Reduksi data merupakan proses berpikir sensitif yang memerlukan kecerdasan, keluasan serta kedalaman wawasan yang tinggi. Hal ini dilakukan sebab data yang diperoleh dari lapangan jumlahnya cukup banyak, maka perlu diperinci dengan cara merangkum, memilih hal-hal yang pokok, memfokuskan pada hal-hal yang penting, dengan mencari tema dan polanya sesuai konsep yang digunakan dalam penelitian ini. Setelah data direduksi, maka langkah selanjutnya adalah melakukan penyajian data yang dilakukan dalam bentuk uraian singkat, hubungan antar kategori, dan sejenisnya (Sugiyono, 2016). Selanjutnya adalah penarikan kesimpulan dan verifikasi dari hasil penelitian. Dalam penelitian ini diperlukan keabsahan data untuk membuktikan apakah data yang diperoleh sudah benar atau belum. Pengujian keabsahan data dalam penelitian ini dilakukan dengan perpanjangan pengamatan, dan teknik triangulasi (Moleong, 2017).

\section{HASIL DAN PEMBAHASAN}

Berdasarkan analisis terhadap data penelitian, ditemukan bahwa Jateng Pos menerapkan empat tipe konvergensi seperti yang dijelaskan Eugenia Siapera dan Andreas Veglis, yakni konvergensi teknologi, konvergensi bisnis, konvergensi profesional dan konvergensi isi. Berikut ini adalah penjabaran masing-masing konvergensi.

Bentuk konvergensi pertama adalah konvergensi teknologi. Konvergensi teknologi yang diterapkan oleh Jateng Pos adalah proses produksi dan distribusi hampir semua jenis materi berita dan informasi dalam berbagai format yang berbeda dengan memanfaatkan berbagai macam perangkat dan platform digital yang berbeda pula. Jateng Pos sebagai media jaringan Jawa Pos yang berada di Jawa Tengah, menyadari bahwa ada wacana tentang senjakala media cetak, namun kepercayaan tersebut juga masih dilawan dengan fakta lapangan bahwa tidak sedikit juga pelanggan yang masih membutukan informasi dan berita dari koran cetak harian. Namun demikian, untuk berusaha menjaga eksistensi media, Jateng Pos juga harus memenuhi kebutuhan generasi millennial dalam mendapatkan informasi dan berita harian dengan meluncurkan Jateng Pos versi online, yakni jatengpos.co.id. 
Selain memanfaatkan media online seperti halaman website tersendiri, Jateng Pos juga aktif di media sosial seperti Instagram, Facebook dan Twitter, dengan membagikan informasi terbaru baik dari Jawa Tengah dan Nasional, dengan data yang dapat dipertanggungjawabkan. Jumlah karakter yang disediakan oleh Twitter dinilai sangat terbatas yakni 140 karakter, sehingga Jateng Pos tetap mencantumkan laman berita resmi mereka bagi siapapun menginginkan informasi yang lebih lengkap dibanding hanya membaca di lini masa Twitter. Jateng Pos merasa perlu hadir di lini masa media sosial, sebab berita-berita yang kerap disebarkan di berbagai media, khususnya online, tidak sedikit merupakan berita palsu (hoax), yang diproduksi hanya untuk keuntungan suatu kelompok saja dan juga untuk menjatuhkan pihak lain. Menurut redaktur Jateng Pos Online, dengan menjaga profesionalitas, Jateng Pos berharap dengan hadir dalam berbagai platform seperti media cetak sendiri atau media online seperti Laman Web, Twitter dan Facebook dapat menetralisir kabar-kabar palsu yang sering beredar di media sosial khususnya mengenai kabar di Jawa Tengah.

Terdapat perbedaan yang menjadi keunikan dari Jateng Pos yakni pemanfaatan media sosial sebagai media untuk membagikan berita dari surat kabar harian dalam bentuk digital. Proses digitalisasi yang dilakukan oleh Jateng Pos yakni dengan mengunggah beberapa halaman ke dalam akun media sosial seperti Instagram, Twitter dan Facebook. Satu halaman penuh diunggah ke akun media sosial pribadi milik Jateng Pos untuk menyasar pembaca media kontemporer. Kurang lebih 10 halaman setiap harinya diunggah dengan harapan memudahkan pembaca untuk mengetahui berita yang disajikan oleh surat kabar harian Jateng Pos pada hari tersebut. Sayangnya kekurangan dari proses digitalisasi ini ialah, kualitas gambar satu halaman penuh koran harian yang diunggah ke media sosial seperti Instagram, Twitter dan Facebook akan mengurangi kualitas gambar sehingga akan sulit untuk dibaca. Berbeda dengan media lain pada umumnya yang hanya mengunggah satu potongan headline berita ke akun media sosial.

Selanjutnya, konvergensi tipe kedua yakni konvergensi bisnis. Konvergensi bisnis yakni proses konvergensi di tingkat bisnis yang mengarah pada bentuk baru pengelolaan organisasi yang dirancang untuk meningkatkan produktivitas dan kesehatan aspek ekonomi media. Dalam proses pengelolaan media online, media lebih mengandalkan data perkembangan kecenderungan khalayak dalam mencari dan menerima informasi di era digital. Tidak jarang data survei mengenai perilaku khalayak dan konsumen berita atau informasi menjadi acuan dalam melakukan inovasi-inovasi seperti digitalisasi dan konvergensi dalam strategi pengelolaan pencarian hingga cara menampilkan hasil berita dan informasi. Dengan melihat pasar yang ada, media melakukan cara dalam mengelola media online dengan dukungan teknologi dan media sosial serta aspek-aspek yang menjadi tren di masyarakat kontemporer untuk dapat menarik minat pengiklan agar ingin mengiklankan produk barang atau jasa mereka melalui media online yang dikelola oleh industri media.

Di Jateng Pos sendiri, menurut redakturnya, media online bukan hanya sebagai pelengkap media saja, dengan melihat potensi pembaca yang sekarang bergeser dari membaca media konvensional ke media online dengan alasan keefektifan, pengiklanpun akhirnya mulai menjadikan media online untuk mengiklankan barang dan jasa. Hal inilah salah satu yang menjadi alasan pengelolaan media online Jateng Pos mulai dilirik oleh pengelola harian Jateng Pos. Dengan mengaplikasikan konsep digitalisasi, media online akan sangat membantu kesehatan dalam bidang bisnis sebuah media, khususnya media lokal untuk tetap menjaring pembaca kontemporer. Dalam persaingan industri media, perusahaan harus melihat kembali dimana pangsa pasar yang akan diambil. Jika pangsa pasar yang diambil adalah masyarakat dengan umur 20-40 tahun, maka produk berita yang dihasilkan dan akan disajikan kepada masyarakat dengan umur 20-35 tahun harus melalui online. Karena generasi tersebut sudah 
mahir menggunakan teknologi dan menganggap kuno hal-hal yang bersifat hardcopy (cetak). Sedangkan pembaca pada rentang usia 36-40 tahun, kebanyakan dari mereka belum mahir menggunakan media online dan lebih nyaman dan lebih mudah membaca berita di koran cetak.

Pada media lokal di Jawa Tengah sendiri, pangsa pasar bukan hanya dilihat dari usia, namun juga kelas sosial. Kelas sosial menengah ke atas pada dewasa ini pun akhirnya menggunakan gawai untuk mendapatkan informasi, berbeda dengan masyarakat kelas menengah ke bawah yang dominan tidak memiliki gawai ataupun tidak mampu menggunakan gawai sehingga masih mengandalkan media dalam bentuk cetak untuk mendapatkan informasi. Oleh karena itu keduanya, baik cetak maupun online harus tetap sama-sama ada untuk menjaga eksistensi media lokal di semua kelas sosial yang ada di daerah. Dengan memproduksi berita versi online dari Jateng Pos, pasar pembaca bukan hanya di wilayah Semarang atau Jawa Tengah saja, namun siapapun yang terhubung dengan Internet akan bisa mengakses berita yang di produksi oleh Jateng Pos dan rekan bisnis. Salah seorang redaktur menyebutkan, mitra untuk memasarkan barang dan jasa akan datang tidak hanya dari wilayah Jawa Tengah saja, tapi darimana saja, sehingga pemasaran pun akan lebih luas. Hal ini akan semakin membantu media lokal di Indonesia akan tetap eksis karena potensi perekonomian dan bisnis yang semakin luas, tidak hanya fokus menyasar satu daerah saja (Sutrisno, 2011).

Fakta lain yang didapatkan dalam penelitian ini adalah Jateng Pos menjadikan konten pariwisata sebagai liputan yang penting untuk para pembaca, melihat objek pariwisata di Jawa Tengah yang sampai saat ini sedang dikembangkan. Minat masyarakat Indonesia yang semakin tinggi untuk melakukan perjalanan ke tempat-tempat wisata ditingkat lokal yang menggambarkan kekhasan suatu daerah. Dengan informasi yang mudah diakses oleh khalayak, Jateng Pos menyediakan informasi yang cukup untuk wisatawan yang ingin melakukan perjalanan, sehingga bisnis di bidang travel pun juga menjadi mitra Jateng Pos dalam hal iklan. Perjalanan dan pariwisata para era saat ini menjadi salah satu sektor yang paling menjanjikan di mana saja potensi pariwisata itu ada. Keputusan para wisatawan untuk melakukan sebuah perjalanan wisata ke suatu tempat sangat dipengaruhi oleh hadirnya media sosial atau media baru. Di mana dalam sebuah penelitian menunjukkan bahwa media sosial mempunyai peran yang cukup penting sebagai sumber informasi utama dalam membantu para wisatawan dalam melakukan perjalanan dan juga mengambil keputusan untuk memilih wisata ke daerah yang akan dituju. Sehingga media cetak lokal mampu mengambil keuntungan dengan memanfaatkan momen ini untuk kemudian memasarkan pariwisata lokal bersama pemerintah daerah dan juga melakukan relasi bisnis dengan jasa perjalanan/travel (Dwityas \& Briandana, 2017).

Walaupun tak dapat dipungkiri bahwa media online akan masuk kedalam arena dan bersaing dengan industri media yang tidak memiliki badan hukum sampai yang memiliki badan hukum, sehingga media cetak yang berhasil memasuki era global sekarang harus berani melakukan langkah-langkah dalam proses digitalisasi ini. Dalam sudut pandang redaksi media Jateng Pos, media online adalah media yang memang memiliki persaingan yang cukup berat dan pesaing yang juga sangat banyak, namun menurut salah seorang redaktur, hal itu tidak akan menyurutkan niat pihak Jateng Pos untuk tetap melakukan konvergensi, minimal untuk dapat menjaga eksistensi dan mengakomodasi iklan-iklan di Jateng Pos.

Berdasarkan data penelitian, ditemukan bahwa Jateng Pos juga melakukan upaya konvergensi tipe ketiga, yakni konvergensi profesional, yang dalam penelitian ini melihat proses jurnalis Jateng Pos beradaptasi dengan teknologi yang berkembang, sehingga membutuhkan keterampilan profesional baru dan sarana organisasi yang juga diperbaharui. Dalam proses produksi berita yang akan ditampilkan dalam situs online Jateng Pos, jurnalis dituntut untuk bisa membuat berita dalam bentuk video. Hal ini disebabkan oleh maraknya 
penggunaan video dalam pemberitaan online yang didukung oleh intensitas penggunaan media sosial untuk mendapatkan informasi. Jateng Pos pun mengupayakan menampilkan beberapa berita dalam bentuk video dengan tidak menghilangkan profesionalitas jurnalis. Dimulai dari proses jurnalistik yakni pengiriman data lapangan ke meja redaktur, dimana informasi yang didapatkan oleh wartawan dilapangan dikirim ke meja redaktur melalui surat elektronik (e-mail). Salah seorang wartawan Jateng mengakui bahwa proses wartawan di lapangan akan lebih dimudahkan dalam proses pengambilan dan pengiriman berita, seperti dalam wawancara dengan salah satu jurnalis media Jateng Pos. Hal tersebut selaras dengan pernyataan tentang pentingnya pelatihan lebih lanjut tentang konvergensi kepada pada jurnalis, khususnya tentang video amatir (Kaltenbrunner \& Meier, 2013).

Hal tersebut diharapkan tidak menjadikan wartawan menyepelekan proses peliputan berita. Dengan kata lain karya jurnalistik yang baik memerlukan proses mengumpulkan informasi yang lakukan langsung dilapangan yang bersifat nyata, bukan digital. Artinya, jurnalis Jateng Pos, khususnya jurnalis muda, tidak keasyikan dalam aplikasi digital atau online dan akhirnya menghasilkan berita yang datanya hanya bersumber dari Internet bukan fakta lapanan. Sehingga hal ini harus diantisipasi tidak hanya oleh profesional bisnis atau industri media massa, tetapi juga oleh lembaga pendidikan yang berhubungan dengan generasi digital natives (Agustin, Karlinah, Abdullah, \& Supriadi, 2013). Selain itu, berbeda dengan berita di media cetak, tulisan wartawan untuk online lebih dipersingkat. Hal ini dilakukan karena karakteristik pembaca di media online adalah pembaca yang 'cepat bosan' membaca berita yang terlalu panjang. Seorang wartawan Jateng Pos mengatakan bahwa pembaca di media online hanya menginginkan inti dari sebuah berita, atau hanya sekedar baca sekilas.

Pengelolaan media online, akan berbeda dengan media cetak, sehingga media yang pada awalnya memiliki background media cetak tidak hanya sekedar mengunggah pemberitaan yang ada di media cetak ke versi online, namun dibutuhkan pengeditan dan trik khusus dalam pengelolaan media versi online. Seperti beberapa kata di versi cetak dalam teknik penulisan waktu menggunakan kata 'kemarin', sedangkan untuk versi online redaktur harus menulis lengkap dengan 'tanggal, bulan, dan tahun'. Menurut salah seorang redaktur, Jateng Pos membuat kebijakan versi cetak akan lebih panjang sekitar tujuh sampai delapan alinea, sedangkan versi online hanya dua sampai tiga alinea, jurnalis hanya memaksimalkan foto, bahkan sekarang trennya adalah berita dalam versi video.

Salah satu tujuan dioperasikannya Jateng Pos versi online adalah untuk mem-viralkan sebuah berita berdasar pada fakta dan kenyataan dilapangan, sehingga bisa dibicarakan di media sosial dan kemudian membawa perubahan. Menurut redaktur, hal ini dipilih karena banyak berita yang diproduksi di Internet hanya mengikuti apa yang viral di sosial media, dan tidak jarang menyalahi kode etik, sehingga harus dipilih baik berita maupun fotoyang akan ditampilkan di media.

Konvergensi tipe keempat yang dilakukan oleh Jateng Pos berdasarkan penelitian iniialah konvergensi isi, yang dalam penelitian ini berarti bahwa produk berita yang dihasilkan oleh wartawan harus sesuai dengan platform yang digunakan, karena isi sebuah jaringan menggabungkan kode komunikasi yang berbeda-beda. Berdasarkan hasil survei dari Hootsuite (we are social) menyebutkan kecenderungan penggunaan Internet di Indonesia adalah didominasi oleh penggunaan platform YouTubeuntuk mengakses video, dengan jumlah mencapai 49\% kemudian disusul Facebook, Instagramdan Twitter (Kemp, 2017). Hasil sebuah penelitian menjelaskan bahwa mahasiswa mengakses Internet kurang lebih 5 jam per hari, diantaranya untuk mengakses media sosial dan instant messenger melalui smartphone (Adiarsi, Stellarosa, \& Silaban, 2015). Saat ini, masyarakat Indonesia menggunakan Internet, baik untuk 
mendapat hiburan maupun untuk mendapatkan informasi adalah dengan melalui video. Hal ini pula yang kemudian menjadi alasan strategi dari pihak Jateng Pos untuk kedepannya akan memperbanyak konten berita dalam bentuk video. Diakui bahwa tren saat ini adalah tulisan dan foto namun untuk kedepan tulisannya sudah sedikit dan diganti video. Berdasarkan data dari Nielsen yang menyatakan bahwa konsumsi konten video online meningkat di semua golongan usia. Hal ini sejalan dengan penelitian internal Jateng Pos tentang pengguna media online, seperti dinyatakan redakturnya, ditemukan fakta bahwa ketertarikan pembaca pada sebuah berita diawali dengan membuka gambar, kemudian video, setelah itu baru membaca berita yang sesuai dengan judulnya yang menarik.

Setiap tahunnya pertumbuhan eksponensial video yang didistribusikan melalui Internet meningkat. Beberapa perusahan media menggunakan laman web mereka untuk menyebarkan informasi dalam bentuk video yang cenderung berbentuk video pendek. Perkembangan jaringan Internet dan teknologi ponsel pintar dan tablet dengan layar yang mendukung untuk melihat video yang jernih telah memungkinkan konsumen untuk menonton video di mana saja. Selama setahun terakhir khususnya, jejaring sosial seperti Twitter dan Facebook telah merangkul tren ini dengan feed berita yang diisi dengan video. Konsumsi video Facebook telah meningkat $75 \%$ dalam setahun terakhir, mencapai 8 miliar tayangan video setiap hari. Survei terbaru Reuters, $79 \%$ dari CEO, editor, dan pemimpin redaksi mengatakan mereka berencana untuk berinvestasi lebih banyak dalam video online tahun ini (Kalogeropoulos, Cherubini, \& Newman, 2018). Faktanya, organisasi berita di seluruh dunia sedang mencoba meningkatkan inovasi kearah video berita, dan seperti yang diidentifikasi oleh PEW Research Center, bahwa produsen dan penyedia jasa video online dapat mengambil alih bisnis media dan mengubah industri surat kabar (Murschetz \& Friedrichsen, 2017).

Maraknya penggunaan video dalam pemberitaan online yang didukung oleh media sosialmembuat banyak penyedia berita online beralih dari berita tulis menjadi berita dalam bentuk video, namun menjamurnya berita dalam bentuk video bukan berarti sejalan dengan profesionalitas jurnalisnya. Tidak sedikit pengunggah (produsen) berita hanya menghasilkan fake news. Hal tersebut pun memberikan nilai negatif pada media online, yang menjadikan rendahnya kepercayaan khalayak pada produk jurnalistik dimedia online. Popularitas media sosial belum diperhitungkan dalam penelitian efek media. Sumber online tidak dianggap lebih dapat dipercaya daripada sumber offline.Khalayak pada umumnya pasif atau acuh tak acuh terhadap penggunaan bahan yang didapat oleh wartawan melalui media sosial (Lecheler \& Kruikemeier, 2016). Hal tersebut yang akan dilawan oleh Jateng Pos sebagai strategi dalam pemberitaan versi online, dengan menyediakan berita dalam bentuk video serta menjaga profesionalitas jurnalisnya. Seperti dinyatakan redaktur Jateng Pos, strategi ini dimulai dengan proses produksi yang melibatkan narasumber yang resmi dan terpercaya, sehingga konten yang dihasilkan juga bisa dipertanggungjawabkan.

Hal serupa telah dilakukan dibeberapa media internasional yang juga didiskusikan dalam kajian manajemen media, bahwa industri media cetak sedang berjuang dengan realitas bahwa ekonomi mereka sulit dan mencari sumber pendapatan baru.Menambahkan konten video di media online mereka adalah upaya mengimbangi hal tersebut (Hallgren \& Nylund, 2018). Dengan perangkat seperti smartphone, tablet, dan televisi pintar, pengguna dapat mengonsumsi video online di mana pun beradadan sesuai keinginan mereka, sehingga media cetak diera saat ini harus memahami kelebihan masing-masing perangkat dan berusaha menjangkau pengguna secara efektif dan hal tersebut yang kemudian diupayakan oleh Jateng Pos untuk menjaga eksistensinya.

Hal lain yang berhubungan dengan konten yang dilakukan oleh Jateng Pos dalam 
menjaga eksistensi media adalah dengan memberikan porsi yang lebih pada berita mengenai pariwisata. Tumbuhnya populasi kelas menengah dan meningkatnya pendapatan masyarakat beberapa tahun terakhir ini menjadi pemicu bergesernya pola konsumsi masyarakat dari membeli barang-barang kebutuhan pokok ke gaya hidup. Penelitian Nielsen Global Consumer menyebutkan bahwa konsumsi masyarakat Indonesia bergeser dari kebutuhan belanja barang menjadi belanja 'pengalaman' dengan cara traveling dan melakukan perjalanan. Disebutkan bahwa angka responden yang memilih untuk berlibur mencapai $37 \%$ sebagai prioritas setelah menabung (Nursastri, 2013). Dengan alasan tersebut pula, khusus untuk media versi online Jateng Pos, fokus (memberi porsi lebih) pada rubrik atau berita dan info traveling. Bahkan diakui pihak Jateng Pos sudah bermain diberita pariwisata sekitar dua tahun setengah. Setiap harinya Jateng Pos bisa upload berita pariwisata sampai 50 berita.

Dalam pemberitaan seputar pariwisata, misalnya dari Semarang, tidak langsung diliput secara umum Semarang, tapi dibedah satu persatu, per-lokasi wisata yang ada. Bahkan untuk satu objek wisata, masih dibagi lagi menjadi beberapa bagian. Begitu juga dengan Usaha Mikro Kecil Menengah (UMKM) yang ada, dari satu objek diambil dari beberapa sudut pandang (angle).Dalam proses peliputan dan pemberitaan pihak Jateng Pos bekerja sama dengan Kementerian Pariwisata, sehingga wartawan Jateng Pos tidak hanya meliput di sekitar Jawa Tengah saja, namun juga di beberapa daerah lain seperti Kalimantan, Sumatera, Sulawesi dan lainnya, dimanapun Kementerian Pariwisata mengadakan kegiatan.

Tabel 2. Ringkasan temuan konvergensi media lokal Jateng Pos di era digital

\begin{tabular}{|c|c|c|c|c|}
\hline & \multicolumn{2}{|c|}{ Proses } & \multicolumn{2}{|c|}{ Produk } \\
\hline & Model Bisnis & $\begin{array}{c}\text { Produksi \& } \\
\text { Distribusi }\end{array}$ & Konsumsi \& Media & Bentuk Utama \\
\hline $\begin{array}{l}\text { Upaya yang } \\
\text { dilakukan }\end{array}$ & $\begin{array}{l}\text { Memanfaatkan } \\
\text { Multi-platform } \\
\text { yang meningkatkan } \\
\text { jumlah dan jenis } \\
\text { pengiklan yang } \\
\text { ingin memasang } \\
\text { iklan di media } \\
\text { online Jateng Pos } \\
\text { User-generated } \\
\text { content, khususnya } \\
\text { untuk penulisan } \\
\text { berita pariwisata }\end{array}$ & $\begin{array}{l}\text { Memperbanyak } \\
\text { konten foto dan } \\
\text { memproduksi berita } \\
\text { dalam bentuk foto. } \\
\text { Membedakan jenis } \\
\text { tulisan berita atau } \\
\text { informasi yang ada } \\
\text { pada versi cetak dan } \\
\text { online. } \\
\text { Memanfaatkan } \\
\text { search engine } \\
\text { Kerjasama dengan } \\
\text { GenPI dalam } \\
\text { produksi berita dan } \\
\text { informasi seputar } \\
\text { wisata } \\
\text { Memanfaatkan } \\
\text { media sosial seperti } \\
\text { Instagram; Twitter; } \\
\text { dan Facebook }\end{array}$ & $\begin{array}{l}\text { Digitalisasi konten } \\
\text { yang di upload } \\
\text { ke akun media } \\
\text { sosial resmi dapat } \\
\text { dinikmati sesuai } \\
\text { dengan kebutuhan } \\
\text { pembaca. } \\
\text { Informasi dalam } \\
\text { bentuk video yang } \\
\text { ditampilkan situs } \\
\text { online. } \\
\text { Tetap } \\
\text { mengandalkan Surat } \\
\text { kabar harian dalam } \\
\text { bentuk Cetak untuk } \\
\text { kalangan pembaca } \\
\text { tertentu. }\end{array}$ & $\begin{array}{l}\text { Surat Kabar Harian } \\
\text { Jateng Pos } \\
\text { Media } \\
\text { onlinejatengpos. } \\
\text { co.id }\end{array}$ \\
\hline $\begin{array}{l}\text { Pihak yang terlibat: } \\
\text { pihak eksternal atau } \\
\text { internal media?? }\end{array}$ & Kedua pihak & $\begin{array}{l}\text { Pihak internal } \\
\text { media }\end{array}$ & $\begin{array}{l}\text { Utamanya pihak } \\
\text { internal media }\end{array}$ & $\begin{array}{l}\text { Pihak internal } \\
\text { media }\end{array}$ \\
\hline $\begin{array}{l}\text { Tipe konvergensi } \\
\text { yang dilakukan }\end{array}$ & Konvergensi Bisnis & $\begin{array}{l}\text { Konvergensi } \\
\text { Profesional }\end{array}$ & $\begin{array}{l}\text { Konvergensi } \\
\text { Konten }\end{array}$ & $\begin{array}{l}\text { Konvergensi } \\
\text { Teknologi }\end{array}$ \\
\hline
\end{tabular}

Sumber: Hasil Penelitian, 2017

Dengan pesatnya minat terhadap gaya hidup traveling khususnya generasi muda, Jateng Pos mengikuti tren tersebut untuk dapat meningkatkan pembaca, khususnya generasi muda. Hal tersebut dibuktikan dengan cara bekerja sama dengan pihak pemerintahan (Kementerian 
Pariwisata) untuk menjalankan sebuah komunitas yang dinamakan Generasi Pesona Indonesia (GenPi). GenPi bertugas untuk membuat konten pariwisata yang kreatif dan menarik untuk diunggah di media online lokal seperti Jateng Pos dan media sosial, maupun untuk memviral-kan berita-berita dari media-media yang memberitakan pariwisata, misalnya GenPi Jawa Tengah bertugas untuk men-viral-kan berita wisata di Jawa Tengah.Selain itu generasi muda, khususnya yang memiliki minat dalam bidang menulis, diberikan ruang oleh Jateng Pos online untuk menuangkan bakatnya dibidang menulis. Tidak jarang Jateng Pos melakukan kerja sama dengan penulis blog (Blogger) untuk mengirim tulisan atau mengisi rubrik traveling yang ada di situs berita online Jateng Pos. Untuk menarik minat generasi muda, pihak Jateng Pos melakukan lomba menulis Blog untuk para bloggeryang banyak mendapat respon positif baik penulis maupun khalayak pembaca.

Dalam Tabel 2 diperlihatkan bahwa Jateng Pos mengadopsi empat tipe konvergensi media yang berkaitan satu sama lain: Jateng Pos melakukan konvergensi teknologi dengan mengelola media online (jatengpos.co.id) dan hadir di media sosial seperti Instagram, Twitter dan Facebook. Selanjutnya konvergensi konten, dimana Jateng Pos versi online, lebih dominan pada konten traveling tidak hanya dalam bentuk tulisan, namun juga foto dan video. Setelah itu, Jateng Pos melakukan konvergensi bisnis, dimana keterhubungan tanpa batas di Internet menambah mitra bisnis (pengiklan) bukan hanya dari Jawa Tengah, tapi seluruh Indonesia. Konten traveling pula menjadikan produsen perlengkapan outdoor berminat mengiklankan produk mereka website Jateng Pos. Terakhir, konvergensi profesional pun dilakukan untuk mempersiapkan SDM yang mampu memproduksi dan mendistribusikan berbagai macam konten yang dibutuhkan berdasarkan platformnya.

\section{SIMPULAN}

Penelitian ini menemukan bahwa Jateng Pos telah mengadopsi empat tipe konvergensi media secara bertahap. Keempat tipe yang diadopsi ini memiliki keterkaitan satu dengan lainnya, seperti berikut: Inovasi pertama adalah konvergensi teknologi, dimana Jateng Pos membentuk dan mengelola media online yakni jatengpos.co.id yang diluncurkan sebagai upaya awal untuk menyasar pembaca muda. Selain media website, Jateng Pos juga hadir di media sosial seperti Twitter dan Facebook untuk menjawab tantangan jaman. Konvergensi teknologi ini kemudian berhubungan pada konvergensi konten, dimana Jateng Pos khususnya versi online, fokus pada konten traveling dengan pertimbangan bahwa tren pembaca media saat ini dominan meminati traveling. Kebutuhan informasi traveling ini dilayani oleh media online sebagai media yang menjadi sumber informasi terkait lokasi tujuan traveling. Selanjutnya, dengan pertimbangan bahwa khalayak saat ini lebih senang mengakses berita melalui foto dan video, pihak Jateng Pos lebih fokus memproduksi berita dengan memperbanyak foto, dan ke depannya akan mulai memproduksi berita berupa audio visual dengan tidak mengesampingkan profesionalitas.

Dengan konvergensi konten dan teknologi yang telah dilakukan Jateng Pos mengakui tidak lagi terbatas lagi oleh masalah geografis, sehingga siapapun yang akan membaca berita dan ingin mendapatkan informasi dari Jateng Pos akan bisa selama terhubung dengan Internet. Sehingga konvergensi bisnis pun dilakukan dengan hadirnya pengiklan yang tidak hanya dari wilayah Semarang atau Jawa Tengah, namun lebih luas dari itu. Konten traveling memberi peluang Jateng Pos mendapatkan pengiklan dari berbagai produsen perlengkapan outdoor yang mengiklankan produk mereka di laman website Jateng Pos. Sejalan dengan konvergensi teknologi, konvergensi bisnis dan konvergensi konten yang dilakukan, maka pihak Jateng Pos harus mempersiapkan Sumber Daya Manusia yang profesional. Oleh karena itu, konvergensi profesional pun dilakukan dengan memberikan pelatihan pada jurnalis tentang proses produksi 
dan distribusi berita yang dibutuhkan berdasarkan platformnya, seperti produksi dan distribusi artikel, foto, maupun video yang nantinya akan di unggah di laman Web, Twitter, Facebook dan Instagram resmi mereka.

Berdasarkan analisis dan kesimpulan, maka terdapat saran mengenai penelitian ini, baik saran teoretis maupun saran praktis, yaitu: (1) Penelitian lanjutan dapat dilakukan dengan menggunakan teori, konsep, pendekatan dan metode penelitian yang berbeda agar memperoleh hasil yang objektif mengenai penggunaan konsep konvergensi media. Jika menggunakan konsep empat tipe konvergensi seperti dalam penelitian ini, maka disarankan untuk tidak memisahkan antara satu dengan yang lainnya, karena berdasarkan kesimpulan ditemukan bahwa konvergensi yang dilakukan oleh media memiliki keterkaitan antara keempat tipe konvergensi tersebut. (2) Saran praktis yang dapat peneliti berikan ialah pengelola media sebaiknya menghindari homogenitas dalam konten media, khususnya online. Dalam konteks jatengpos.co.id, keputusan untuk memberikan porsi yang lebih banyak pada media online untuk liputan pariwisata akan berimbas pada seragamnya konten, dimana liputannya hanya berisi tentang liputan pariwisata saja, sehingga informasi lain yang lebih dibutuhkan oleh masyarakat Jawa Tengah tidak lagi dipenuhi dengan baik.

Selain kepada pengelola media, saran yang dapat peneliti berikan kepada pembaca media ialah, sebaiknya khalayak dalam mencari informasi untuk satu kejadian melalui media online tidak hanya sekedar membaca satu artikel saja, sebab berdasarkan penelitian ini, media yang telah melakukan konvergensi teknologi dan konvergensi konten, akan cenderung membagi satu berita menjadi beberapa artikel, sehingga dalam satu artikel untuk sebuah kejadian belum mampu disajikan secara lengkap. Oleh karena itu, khalayak harus membaca berbagai artikel untuk dapat melengkapi fakta lain dari sebuah kejadian.

\section{DAFTAR PUSTAKA}

Adiarsi, G. R., Stellarosa, Y., \& Silaban, M. W. (2015). Literasi Media Internet di Kalangan Mahasiswa. Humaniora, 6(4), 470. https://doi.org/10.21512/humaniora.v6i4.3376

Agustin, H., Karlinah, S., Abdullah, A., \& Supriadi, D. (2013). Pemetaan Kebutuhan Kualifikasi Jurnalis Pemula pada Industri Media Massa di Indonesia. Jurnal Kajian Komunikasi, 1(2), 141. https://doi.org/10.24198/jkk.v1i2.6039

APJII. (2017). Hasil Survei Penetrasi dan Perilaku Pengguna Internet Indonesia 2017. In Asosiasi Penyelenggara Jasa Internet Indonesia.

Ayunita, V. (2013). Strategi Manajemen Suara Merdeka Untuk Mempertahankan Emsistensi Perusahaan dalam Menghadapi Media Kompetitor di Jawa Tengah. Interaksi Online, 02(03).

Dhiya, A., \& Fadilah, E. (2018). Transformasi Harian Kompas Menjadi Portal Berita Digita Subscription Kompas . Id. Kajian Jurnalisme, 01, 190-213.

Dwityas, N. A., \& Briandana, R. (2017). Social Media in Travel Decision Making Process. International Journal of Humanities and Social Sciences, 7(7), 291-292.

Fidler, R. (2003). Mediamorfosis. Yogyakarta: Bentang Budaya.

Hallgren, N., \& Nylund, M. (2018). Online Videos at Newspaper Websites : A Literature Review. The Journal of Media Innovations, 4(2), 71-79. https://doi.org/http://dx.doi. org/10.5617/jomi.v4i2.2339

Holmes, D. (2005). Communication theory: Media, technology, society. In Communication Theory: Media, Technology, Society. https://doi.org/10.4135/9781446220733

Kalogeropoulos, A., Cherubini, F., \& Newman, N. (2018). The Future of Online News Video. Reuters Institute, University of Oxford, 1-21. 
Volume 03 Nomor 02 Tahun 2020

DOI: $10.24198 / \mathrm{jkj} . \mathrm{v} 3 \mathrm{i} 2.25070$

Kaltenbrunner, A., \& Meier, K. (2013). Convergent journalism-Newsrooms, routines, job profiles and training. In Media and Convergence Management (pp. 285-298). https://doi. org/10.1007/978-3-642-36163-0_19

Karman. (2017). Disruptif Teknologi Internet Dan Eksistensi Media Cetak Internet Technology Disruption and the Print Media Exictence. Jurnal Kementerian Komunikasi Dan Informatika, Direvisi(9), 12-12.

Kemp, S. W. A. S. (2017). Digital in 2017: Southeast Asia. In We Are Social.

Khadziq, K. (2016). KONVERGENSI MEDIA SURAT KABAR LOKAL (Studi Deskriptif Pemanfaatan Internet Pada Koran Tribun Jogja dalam Membangun Industri Media Cetak Lokal). Profetik: Jurnal Komunikasi, 9(1). https://doi.org/10.14421/pjk.v9i1.1187

Kolodzy, J., Grant, A. E., DeMars, T. R., \& Wilkinson, J. S. (2014). The convergence years. Journalism and Mass Communication Educator, 69(2), 197-205. https://doi. org/10.1177/1077695814531718

Kriyantono, R. (2014). Teknik Praktis Riset komunikasi. Jakarta: Prenada Media Group.

Lecheler, S., \& Kruikemeier, S. (2016). Re-evaluating journalistic routines in a digital age: A review of research on the use of online sources. New Media and Society, Vol. 18, pp. 156-171. https://doi.org/10.1177/1461444815600412

Lundén, K. (2009). The Death of Print? The Challenges and Opportunities facing the Print Media on the Web. Oxford: Reuters Institute for the Study of Journalism.

Moleong, L. J. (2017). Metodologi Penelitian Kualitatif (Edisi Revisi). In PT. Remaja Rosda Karya (p. 424).

Murschetz, P. C., \& Friedrichsen, M. (2017). Does Online Video Save Printed Newspapers? Online Video as Convergence Strategy in Regional Printed News Publishing: The Case of Germany. In Digital Transformation in Journalism and News Media (pp. 115-128). https://doi.org/10.1007/978-3-319-27786-8_10

Nugroho, Y., Siregar, M. F., Laksmi, S., \& Media, E. (2012). Memetakan Kebijakan Media di Indonesia. Jakarta: Centre for Innovation Policy and Governance.

Nursastri, S. A. (2013). Kini, Traveling Jadi Prioritas Kedua Orang Indonesia.

Price, G. (2015). Opportunities and Challenges for Journalism in the Digital Age : Asian and European Perspectives. The Asia-Europe Meeting (ASEM) Summit, (August), 1-15.

Prihartono, A. W. (2016). Surat Kabar \& Konvergensi Media (Studi Deskriptif Kualitatif Model Konvergensi Media Pada Solopos). CHANNEL: Jurnal Komunikasi, 4(1). https:// doi.org/10.12928/channel.v4i1.4210

Rakhmat, J. (2009). Metode Penelitian Komunikasi. Bandung: Remaja Rosdakarya.

Rusadi, U. (2014). Konsumsi Berita Lintas Media Massa Konvensional Dan Internet. In Jurnal Penelitian dan Pengembangan Komunikasi dan Informatika (Vol. 4).

Salman, A., Ibrahim, F., Abdullah, M. Y. H., Mustaffa, N., \& Mahbob, M. H. (2011). The impact of new media on traditional mainstream mass media. Innovation Journal, 16(3).

Samatan, N. (2009). Strategi Pengembangan Media: Antara Bisnis dan Ideologi. Jurnal Ilmiah Ekonomi Bisnis, 14(3).

Siapera, E., \& Veglis, A. (2012). The Handbook of Global Online Journalism. In The Handbook of Global Online Journalism. https://doi.org/10.1002/9781118313978

Sugiyono. (2016). Memahami Penelitian Kualitatif. Bandung: Alfabeta.

Sutrisno, P. S. (2011). Fenomena Kebangkitan Industri Pers Daerah/Media Lokal. Jurnal Dewan Pers, 5, 77-90.

Vebrynda, R., Maryani, E., \& Abdullah, A. (2017). Konvergensi Dalam Program NET Citizen Journalism. Jurnal Kajian Komunikasi, 5(1), 53. https://doi.org/10.24198/jkk.v5i1.7432 
152 | Kajian Jurnalisme

Volume 03 Nomor 02 Tahun 2020

DOI: $10.24198 /$ jkj.v3i2.25070

Wheelen, T. L., \& Hunger, J. D. (2015). Strategic Management and Business Policy - Toward Global Sustainability. In Pearson.

Yin, R. K. (2018). Studi Kasus: Desain dan Metode. Jakarta: RajaGrafindo Persada. 